EASTERN EUROPEAN JOURNAL OF TRANSNATIONAL RELATIONS

2019 Vol. 3 No. 1

DOI: 10.15290/eejtr.2019.03.01.05

Agnieszka Przygoda ${ }^{1}$

British American Tobacco², London, United Kingdom

\title{
The International Registration of Trade Marks under the Madrid System: Advantages and Disadvantages
}

\begin{abstract}
The objective of this article is to present an overview, the advantages and disadvantages of the International Registration of Marks under the Madrid System. With over 1.3 million trade marks registered, the Madrid System is the top choice for international trade mark registration among multinational companies. There are three possible routes that traders might take to register a trade mark: national, European or international. A national registration system for trade marks provides protection at a national level only. Registration at the EU level through a single application to the European Intellectual Property Office (EUIPO) in Alicante, Spain provides protection in all 28 EU Member States. International registration of marks under the Madrid System, administered by the International Bureau of the World Intellectual Property Organization (WIPO) in Geneva, Switzerland enables traders to obtain protection in a number of different jurisdictions via a single application. This article will focus on the description of the main features of international registration of marks under the Madrid System, its advantages and disadvantages which should be considered by traders before deciding which route to take in order to protect their trade mark.
\end{abstract}

Keywords: Trade Marks, Intellectual Property, Madrid Protocol, Madrid Agreement, International Registration of Marks, Madrid System, The World Intellectual Property Organization

1 Assistant Trade Mark Counsel (British American Tobacco, London), Chartered UK Trade Mark Attorney, Professional Certificate in Trade Mark Practice, Nottingham Trent University, Certificate in Trade Mark Law and Practice, Queen Mary University of London, Master in Intellectual Property, University of Alicante. ORCID: https://orcid.org/0000-0002-7916212X. E-mail: agnieszkaprzygoda@gmail.com.

2 The information and views set out in this article are those of the author and do not necessarily reflect the official opinion of the company. 


\section{Introduction and an Overview of the Madrid System}

The international filing system was established under the 1891 Madrid Agreement and the 1989 Madrid Protocol. All member states of the Paris Convention for the Protection of Industrial Property may become a party to the Agreement or the Protocol or both. The Agreement and the Protocol are "independent, parallel treaties with separate, but overlapping, memberships" (Keeling, et al., 2018, p. 255). The relationship between the two instruments is complex and will not be addressed in detail in this article. The Madrid Agreement provided for trade marks registered in one country to be extended to other countries. The system worked reasonably well in those countries that used it but, as a result of a number of perceived defects, failed to attract many adherents (Keeling, et al., 2018, p. 254). Some European countries have ratified the Madrid Agreement. However, its provisions were unacceptable to certain countries, including the UK, Denmark, Ireland and Greece in Europe and, elsewhere, the US, Australia and Japan (Davis, St Quintin, \& Tritton, 2018, 3-053). Under the Madrid Agreement, the international registration followed a "home" registration almost automatically. This gave an advantage to nationals of states who could obtain a home registration comparatively easily (Seville, 2009, p. 216). In an attempt to make the system attractive to a wider range of countries the Agreement was complemented by a Protocol (Keeling, et al., 2018, p. 254). Under the system created by the Madrid Protocol, the formalities relating to applications for international registrations of a trade mark are examined by the WIPO International Bureau, which then transmits valid applications to the competent authorities of those contracting parties designated by the applicant to examine substantive matters relating to the application (Dinwoodie \& Janis, 2008, p. 239). In 2015, Algeria, the last of the members of the Madrid Agreement who had not acceded to the Madrid Protocol, acceded to the Madrid Protocol. As under the Madrid Agreement, the Madrid Protocol alone applies to countries which have ratified both the Madrid Agreement and the Protocol; the Madrid Agreement is no longer relevant and can be considered a "dead" treaty. This is because future applicants can only accede to the Madrid Protocol. Accordingly, all international registrations are governed solely and exclusively by the Madrid Protocol (Davis, St Quintin, \& Tritton, 2018, 3-054).

According to the Guide to the International Registration of Marks under the Madrid Agreement and the Madrid Protocol, the international filing system may be used only by a natural person or a legal entity which has a real and effective industrial or commercial establishment in, or is domiciled in, or is a national of, a country which is party to the Madrid Agreement or the Madrid Protocol, or which has such an establishment in, or is domiciled in, the territory of an intergovernmental organization which is a party to the Protocol, or is a national of a member State of such an organization (WIPO, Guide to the International Registration of Marks under the Madrid Agreement and the Madrid Protocol, 2018, Part A, para. 02.07). 
In order to apply for international registration for a mark under the Protocol, an application for registration must have been made in a country that is party to the Protocol (Bently \& Sherman, 2014, p. 908). The Madrid Union currently has 104 members, covering 120 countries. According to the data on the WIPO's website, these members represent more than $80 \%$ of world trade, with potential for expansion as membership grows (WIPO, Members of the Madrid Union, 2019). The list of members or otherwise called "Contracting Parties" might be found on WIPO's website. The existing registration and application provide the 'national basis' that grounds the Protocol application. Applications for international registration are filed in the office in which the national basis was filed (Bently \& Sherman, 2014, p. 908909). For example, a company based in the United Kingdom which filed a trade mark application with the United Kingdom Intellectual Property Office (UKIPO) can use this application as a basic application to file a single international application with the same office designating a number of countries, members of the Madrid Union. The office of origin examines the international application to ensure it corresponds to the basic application or registration. Once the formalities check is completed, it forwards the application to WIPO, which examines the application to ensure it complies with the Protocol. Subsequently, WIPO publishes the mark on the International Register of Trade Marks and forwards details of application to each of designated countries which examine the mark according to its own criteria for registration and have to notify WIPO of any refusal within usually 18 months.

The Madrid system is the only global registration system for marks, supporting activity in markets that account for over $80 \%$ of world trade (WIPO, Protecting your Marks Abroad. The Madrid System., 2013, p. 6), and has been a huge success for both applicants and national Intellectual Property Offices of contracting parties. It plays an important role in supporting economic growth and encouraging innovation in the contracting parties. Whereas WIPO was initially created to serve primarily as the secretariat of intergovernmental treaties and treaty negotiations, its activities have increased enormously over the past four decades. The organization's growing workload has been due in part to the rising use of its global protection system treaties (Birkbeck, 2016, p. 9). According to WIPO's statistics, Madrid international applications totalled 53,493 in 2016 making it the highest number of international applications ever filed. The highest numbers of international applications were filed by applicants domiciled in the United States $(7,730)$ and Germany $(7,544)$ (WIPO, WIPO IP Facts and Figures 2017, 2017, p. 26). The international filing system is extensively used by multinational companies operating globally. In 2016, by filing 150 applications, the French company L'Oréal became the top Madrid applicant for the first time. It was followed by the British company Glaxo Group (141 applications), German's BMW (117 applications) and Lidl (112 applications) and the Swiss company, Novartis (94 applications), which after holding the top spot for five years in a row, dropped to fifth position in 2016 (WIPO, Madrid Yearly Review 
2017, 2017, p. 7). According to the Madrid Yearly Review 2018, for the second year in a row, the French company L'Oréal heads the list of top Madrid applicants in 2017 by filing almost 200 applications (WIPO, Madrid Yearly Review 2018, 2018 , p. 38). WIPO provides access to intellectual property statistics on its website which are considered an important tool to understand trends in policy, business, and technology worldwide.

\section{Advantages of the Madrid System}

Decisions to register and the choice of routes are likely to involve commercial judgements as to the likely markets in which protection is desired compared with the cost of obtaining registrations for such territories (Bently \& Sherman, 2014, p. 911). This part of article highlights the main advantages of the Madrid System and the main reasons for choosing this route by traders. It is important to analyse the advantages as well as disadvantages of the Madrid System in order to make an informed decision on how to best protect the trade mark and whether the benefits of the protection obtained are equivalent to the cost spent in seeking that protection.

\section{Single Application}

The main advantage of international registration is that instead of trade mark holders having to file a series of applications in each of the jurisdictions in which they would like protection, they are able to obtain protection in a range of jurisdictions with a single application (Bently \& Sherman, 2014, p. 907). International registration does not lead to something such as an "international mark", so much as it does facilitate the acquisition of national marks (Bently \& Sherman, 2014, p. 907). According to Sir Robin Jacob et al. in the Guidebook to Intellectual Property "What is not obtained by so called 'international' registration is a true international registration - a single registration taking effect in a number of countries. You simply get a bunch of national registrations" (Jacob, Alexander, \& Fisher, 2014, Part III, Chapter 13). The application for international registration can be filed in one of the three official languages of WIPO: English, French and Spanish. The international registration must be filed by completing a single form MM2 rather than a number of national forms in various national languages. This form must be sent to the office of origin, but it must not be sent directly to WIPO. The applicants avoid the necessity of filing trade mark applications using local languages of each designated country and paying for translations or hiring a representative in each country. After filing an application in or obtaining a registration from an Office of Origin, the mark owner needs only to file a single application in one language and pay fees in one currency to one office (Gilson \& Gilson Lalonde, 2003, p. 29). There is also no need 
to have a direct correspondence with the national offices of designated countries unless a provisional refusal is issued locally. Moreover, the holder does not have to wait for the Office of each Contracting Party in which protection is sought to take a positive decision to register the mark. If no refusal is notified by an Office within the applicable time limit of 18 months, the mark is protected in the Contracting Party concerned. In some cases, the holder does not even have to wait the expiry of this time limit in order to know that the mark is protected in a Contracting Party, since he may, before the expiry of the time limit, receive a statement of grant of protection from the Office of that Contracting Party (WIPO, The Madrid System for the International Registration of Marks. Objectives, Main Features, Advantages, 2016, p. 11).

From the date of the international registration, the protection of the mark in each of the designated Contracting Parties is the same as if the mark had been the subject of an application for registration filed directly with the Office of that Contracting Party. If no provisional refusal is notified to the WIPO within the relevant time limit, or if any such refusal is subsequently withdrawn, the protection of the mark in each designated Contracting Party is the same as if it had been registered by the Office of that Contracting Party. An international registration is therefore equivalent to a bundle of national registrations (WIPO, The Madrid System for the International Registration of Marks. Objectives, Main Features, Advantages, 2016, p. 7). This is in contrast to a unitary regional right such as the European Union trade mark, which cannot be refused, limited or transferred with effect for only a part of the territory covered by the right, and which may be enforced by a single legal action covering infringement occurring anywhere in that

territory (WIPO, The Madrid System for the International Registration of Marks. Objectives, Main Features, Advantages, 2016, p. 8).

\section{Cost-effective}

The Madrid System provides a low-cost and effective solution for obtaining and maintaining trade mark protection in multiple markets (WIPO, How to Use the Madrid System: Benefits of the Madrid System, 2019). The low-cost of multinational filing programme via a single application is in practice considered the most important advantage of the Madrid System. This route of filing is usually chosen by multinational companies which would like to obtain trade mark protection globally. WIPO, the Trade Mark Offices in the country of origin and designated countries charge fees for their operations and efforts in processing the international registration. The holder of an international application governed by the Protocol will have to pay to WIPO two and in some cases three separate fees (Keeling, et al., 2018, p. 256), namely: a basic fee, a separate fee with respect to each designated 
country and a supplementary fee if the application covers good and services in more than three classes of the Nice Classification, an international classification of goods and services. Approximately half of the Contracting Parties have elected to receive an individual fee, including UK and the EU (Keeling, et al., 2018, p. 256). For example, when designating the EU, the applicant will have to pay (in Swiss francs) the standard fee of $€ 850$ for one class. On the other hand, when designating Russia which has not elected to charge the individual fee, the applicant will have to pay the additionalfee of CHF 100. The office of origin usually charges a "handling fee" for an international registration. The fee for filing international registration through EUIPO as the office of origin is $€ 300$. The WIPO website provides an online fee calculator where it is possible to select the countries of interest to designate and it automatically calculate the total fee in Swiss francs (CHF). The Madrid System is a very cost-effective option for an applicant who would like to obtain trade mark protection internationally in a number of countries and especially when it has plans for future expansion as the Madrid System offers the possibility of further designations of additional countries at anytime after the international application is filed. If the applicant is interested in obtaining trade mark protection in less than four countries with no plans for expansion, national filings might be a better option here.

\section{Centralised Administration}

Once the mark has been recorded in the International Register, the Madrid System makes it possible for the holder to manage the international registration via a single centralized system (WIPO, How to Manage your International Registration: Overview, 2019). The trade mark owner can modify, renew or expand the global trade mark portfolio through a single request. For example, a single request is sufficient to transfer or renew the international registration in multiple countries, or to appoint a new representative before WIPO. An international registration is valid for 10 years and can be renewed for further period of ten years by filing a single request directly with WIPO which reminds the holder of international registration six months before the expiry of the term of protection that the international registration is due for renewal. A major advantage of the international registration system is that even though it covers many countries, only a single renewal fee is paid to renew the registration (Eastaway, Gallafent, Dauppe, \& Kimber, 2013, 4-019). It is also possible to record changes to the trade mark owner's name and address, request a change in ownership, or restrict the scope of the international registration. However, recording a license in the International Register which has the same effect as registering a license directly with each national/regional IP Office, will have no effect in a particular country. For instance, recording a license in the International Register has no effect in Japan. The trade mark holder would 
therefore, need to file a request to record a license of an international registration to take effect in Japan directly before the JPO in accordance with national requirements (The Madrid Highlights, 2018, p. 3). Therefore, it is recommended to always check the local requirements in each designated country before recording a license in the International Register.

\section{Disadvantages of the Madrid System}

There are few limitations of the Madrid System that should be taken into consideration when filing the international registration is considered. These limitations do not always apply, and everything should be assessed on a case-bycase basis. This article's aim is to highlight the most important disadvantages of the Madrid System which when ignored can result in the loss of rights or restricted scope of protection.

\section{Central Attack}

During the first five years from the date of the international registration, the protection resulting from the international registration may not be relied upon if any basic application upon which the international registration was based is refused, or any basic registration is invalidated, revoked, or otherwise challenged. The defeat of an international registration as to all designated Contracting Parties through invalidation of its basic application or registration is known as "central attack" (Gilson \& Gilson Lalonde, 2003, p. 20). In practice, any third party wanting to challenge the international registration in all designated countries is advised to attack the basic application or basic registration ("home mark"). If the basic registration is cancelled after the five years as a result of an action that began during the fiveyear period, the international registration will likewise be cancelled. If, for instance, an opposition is filed against the basic registration within the five-year period that results in rejection of the application after the five-year period, the international registration will be cancelled upon rejection of the application (Gilson \& Gilson Lalonde, 2003, p. 21). There are strategies available to minimise risks associated with the five-year dependency period. For example, if an international registration is to be based on a basic application, it is recommended to wait until the opposition period is over before filing the international registration. This will give an indication to the applicant whether there is any third party interested in challenging the applicant's mark. If the basic registration has never been used before and there is no firm intention to use it in the "home country", the right holder must consider the possibility that any third parties might attempt to cancel it due to non-use. 
The European Union has become a contracting party of the Protocol to the Madrid Agreement Concerning the International Registration of Marks. This allows European Trade Marks to be the basis for an international registration, and protection of an international registration to be extended not only to the individual Members States of the European Union party to the Madrid System but also to the European Union as a whole (Alexander von Mühlendahl, et al., 2016, p. 7). According to Article 18 of the European Union Trade Mark Regulation, if, within a period of five years following registration, the proprietor has not put the EU trade mark to genuine use in the Union in connection with the goods or services in respect of which it is registered, or if such use has been suspended during an uninterrupted period of five years, the EU trade mark shall be subject to the sanctions provided for in this Regulation unless there are proper reasons for non-use. For example, if the EUTM was registered on 01/01/2011, it became subject to revocation on 02/01/2016. If the application for revocation was filed on 15/09/2016, the EUTM proprietor would have to prove genuine use of its mark within the period from 15/09/2011 to 14/09/2016 (EUIPO Guidelines, Part D, 2017, p. 7). The period of non-use can vary in each country and can be shorter than five years. If the basic registration is lost for example due to revocation based on non-use, all of the other registrations are also lost.

Where there has been a successful central attack on the home mark, the proprietor may seek to transform his international registration into such national registrations, and if he makes such an application within three months after the cancellation of the international registration, he will keep his priority date (Michaels \& Norris, 2014, p. 121). The national registrations resulting from the transformation are examined under the national laws and the applicant will have to pay a national application fee in each country where the transformation request was made. In practice, the transformation requests are rare and are recommended in a situation where it is crucial for the applicant to maintain the original filing or priority date. Once the fiveyear period has safely passed, even the revocation of the mark in the home territory will not affect the validity of the other national registrations (Michaels \& Norris, 2014, p. 122).

\section{“Home Mark” Requirement}

In order to use the system, in addition to holding trade mark application or registration in a Protocol member country, it is necessary to have one of three specified links with the same Protocol member country, namely:

(1) be a national of a Protocol member country;

(2) be domiciled in a Protocol member country; or

(3) have a real and effective industrial or commercial establishment in a Protocol member country (Keeling, et al., 2018, p. 255). 
For instance, a UK based corporation having a trade mark application in the UK can use it as a basic application for the purposes of international registration. In case of the EU it is necessary to be a national of an EU Member State or have a domicile or real and effective industrial or commercial establishment in EU territory (Keeling, et al., 2018, p. 255). For example, A French national domiciled in Switzerland who owns European Trade Mark is entitled to file international registration and use his European Trade Mark as a basic registration only based on his nationality (however, in this case, a representative before the EUIPO must be appointed). A Swiss company with no domicile or real and effective industrial or commercial establishment in an EU Member State is not entitled to file an international application through the EUIPO (EUIPO Guidelines, Part M, 2017, p. 7-8) as the office of origin. On the other hand, a Swiss company who holds a Swiss national trade mark application or registration is entitled to file an international application through the Swiss Federal Institute of Intellectual Property as the office of origin. It is important to note that choosing the EUTM as a basic application or registration for international registration creates greater risk of central attack. EUTM can be challenged if there are any absolute or relative grounds for refusal present in any of the $28 \mathrm{EU}$ Member States. For instance, the sign must be refused if it is descriptive in any of the official languages of the European Union, regardless of the size or population of the respective country (EUIPO Guidelines, Part B, 2017, p. 4). The requirement of "home mark" creates difficulty for a person or corporation which does not have any of those links. For instance, an international registration cannot be assigned to a party who does not have either a commercial establishment, domicile or nationality in a country that is a member of the Madrid Protocol (Liss \& Adin, 2012, p. 318).

\section{Restriction on the Change in Ownership}

In order to be entitled to own the international registration, a new owner (the transferee) must have a business or domicile in a Contracting Party (member) of the Madrid System or be a national of a Contracting Party (WIPO, How to Manage your International Registration: Change in Ownership, 2019). Under the Protocol, the International Bureau is required to record in the International Register any change in the ownership of an international registration, with respect to any of the designated countries, at the request of the holder of the registration or of the Office concerned made ex officio or at the request of an interested person (Keeling, et al., 2018, p. 263). To record a change in ownership, the official form MM5 must be submitted to the WIPO. The form must indicate the Contracting Party through which the new owner is entitled to use the Madrid System whether through nationality, domicile and/or a real and effective industrial or commercial establishment. This restricts the 
ability of individuals or companies which are not entitled to use the Madrid System to purchase the international registrations.

\section{Country Specific Limitations}

There are a number of country specific limitations to international registration which should be considered before designating those countries through the Madrid System. Therefore, the potential applicants should always check the local requirement on a case-by-case basis. WIPO has created the Madrid Member Profiles which describes the local practice of all Contracting Parties. This online tool is useful especially where the applicant has no knowledge about the practice of the local offices of designated countries. For example, China uses the Nice International Classification of Goods and Services which is divided into 45 classes. Additionally, based on Article 2 of the Nice Agreement, each of the 45 classes is further divided into sub-classes serving as reference used by the examiner in determining the similarity of goods and services in compliance with the practice of China National Office (WIPO, Madrid Member Profiles, 2019). If trade mark protection through the Madrid System is sought in China, the applicant should be aware of the sub-classes coverage gaps which do not occur where national Chinese trade mark application is put in place.

The scope of the rights arising from international registration and the limitations are determined by the contents of the trade mark law of the state in question (Cohen Jehoram, Van Nispen, \& Huydecoper, 2010, p. 18). International registrations are limited to the original list of goods and services covered by the basic application or registration. This means that any subsequent designation will cover the same goods and services as the basic application or registration. For instance, the US requires narrower and more specific product categories than many other countries, and this limits the future scope of a Madrid-registered mark (Merges \& Haiyan Song, 2018, 17.1.3.2.1) if it is based on the US home application or registration.

\section{Conclusion}

The Madrid System is a top choice among the traders to protect their trade marks globally. The system is especially popular among the multinational companies trading globally. The potential applicants in deciding which route to take, national, European or international, should take into account a number of factors and compare the benefits and limitations of all three filing systems. The most significant factor in choosing the trade mark protection through the international registration under the Madrid System is probably its low cost when compared to other choices of protection. It is also easy to file the international application by filing in a single application 
form and submitting it to a single office. In practice, the multinational companies which fulfil "home mark" requirement can file the international application directly without using a representative. Therefore, in addition to the low cost of this option, it also saves the applicant's time and resources. International registration is also to the advantage of Trade Mark Offices. They do not need to examine for compliance with formal requirements, or classify the goods or services, or publish the marks (WIPO, The Madrid System for the International Registration of Marks. Objectives, Main Features, Advantages, 2016, p. 12). When considering taking this route, a note should be taken of the downsides of the Madrid System which are also the subject of this article. However, when weighing up the benefits and limitations of the Madrid System, its benefits prevail which is reflected in the increasing number of international application made by multinational companies.

\section{REFERENCES}

Bently, L., \& Sherman, B. (2014). Intellectual Property Law 4th Edition. Oxford: Oxford University Press.

Birkbeck, C. D. (2016). The World Intellectual Property Organization (WIPO): A Reference Guide. Cheltenham: Edward Elgar Publishing Limited.

Cohen Jehoram, T., Van Nispen, C., \& Huydecoper, T. (2010). European Trademark Law: Community Trademark Law and Harmonized National Trademark Law. Kluwer Law International.

Davis, R. D., St Quintin, T., \& Tritton, G. (2018). Tritton on Intellectual Property in Europe. 5th Edition. London: Sweet \& Maxwell.

Dinwoodie, G. B., \& Janis, M. D. (2008). Trademark Law and Theory. A Handbook of Contemporary Research. Cheltenham: Edward Elgar Publishing Limited.

Eastaway, N., Gallafent, R., Dauppe, V., \& Kimber, J. (2013). Intellectual Property Law and Taxation. 8th Edition. London: Sweet \& Maxwell.

EUIPO. (2017). Guidelines for Examination of European Union Trade MArks Part B Examination Section 4 Absolute Grounds for Refusal Chapter 4. Retrieved from EUIPO: https://euipo. europa.eu/tunnel-web/secure/webdav/guest/document_library/contentPdfs/law_and_ practice/trade_marks_practice_manual/WP_2_2017/Part-B/04-part_b_examination_ section_4_absolute_grounds_for_refusal/part_B_examination_section_4_chapter_4/ part_B_ex

EUIPO. (2017). Guidelines for Examination of European Union Trade Marks Part D Cancellation Section 2 Substantive Provisions. Retrieved from EUIPO: https://euipo.europa.eu/tunnel-web/ secure/webdav/guest/document_library/contentPdfs/law_and_practice/trade_marks_practice_ manual/WP_2_2017/Part-D/02-part_d_cancellation_section_2_substantive_provisions/ part_d\%20cancellation_section_2_substantive_provision

EUIPO. (2017). Guidelines for Examination of European Union Trade Marks Part M International Marks. Retrieved from EUIPO: https://euipo.europa.eu/tunnel-web/secure/webdav/guest/ 


\section{EASTERN EUROPEAN JOURNAL OF TRANSNATIONAL RELATIONS}

document_library/contentPdfs/law_and_practice/trade_marks_practice_manual/WP_2_2017/ Part-M/01-part_m_international_marks/part_m_international_marks_en.pdf

Gilson, J., \& Gilson Lalonde, A. (2003). The Madrid Protocol: A Slumbering Giant Awakens at Last. Newark, San Francisco: Matthew Bender \& Company, Inc.

Jacob, R., Alexander, D., \& Fisher, M. (2014). Guidebook to Intellectual Property. Sixth Edition. Hart Publishing.

Keeling, D., Llewelyn, D., Mellor, J., Tom Moody-Stuart, Q., Berkeley, I., Chantrielle, A., \& Duncan, W. (2018). Kerly's Law of Trade Marks and Trade Names 16th Edition. London: Sweet \& Maxwell.

Liss, E., \& Adin, D. (2012). Intellectual Property Law and Practice in Israel. Oxford: Oxford University Press.

Merges, R. P., \& Haiyan Song, S. H. (2018). Transnational Intellectual Property Law: Text and Cases. Cheltenham: Edward Elgar Publishing Limited.

Michaels, A., \& Norris, A. (2014). A Practical Guide To Trade Mark Law Fifth Edition. Oxford: Oxford University Press.

Seville, C. (2009). EU Intellectual Property Law and Policy. Cheltenham: Edward Elgar Publishing Limited.

Von Mühlendahl, A., Botis, D., Maniatis, S., \& Wiseman, I. (2016). Trade Mark Law in Europe. Third Edition. Oxford: Oxford University Press.

WIPO. (2013). Protecting your Marks Abroad. The Madrid System. Retrieved from WIPO: https:// www.wipo.int/edocs/pubdocs/en/marks/1039/wipo_pub_1039.pdf

WIPO. (2016). The Madrid System for the International Registration of Marks. Objectives, Main Features, Advantages. Retrieved from WIPO: https://www.wipo.int/edocs/pubdocs/en/wipo_ pub_418_2016.pdf

WIPO. (2017). Madrid Yearly Review 2017. Retrieved from WIPO: https://www.wipo.int/edocs/ pubdocs/en/wipo_pub_940_2017.pdf

WIPO. (2017). WIPO IP Facts and Figures 2017. Retrieved from WIPO: https://www.wipo.int/edocs/ pubdocs/en/wipo_pub_943_2017.pdf

WIPO. (2018). Guide to the International Registration of Marks under the Madrid Agreement and the Madrid Protocol. Retrieved from WIPO: https://www.wipo.int/export/sites/www/madrid/en/ guide/guide.pdf

WIPO. (2018). Madrid Yearly Review 2018. Retrieved from WIPO: https://www.wipo.int/edocs/ pubdocs/en/wipo_pub_940_2018.pdf

WIPO. (2018). Special Edition of the Madrid Highlights. The Japan Patent Office (JPO) as Designated Contracting Party (DCP). Retrieved from WIPO: https://www.wipo.int/export/sites/www/ madrid/en/highlights/2018/madrid_highlights_1_2018.pdf

WIPO. (2019). How to Manage your International Registration: Change in Ownership. Retrieved from WIPO: https://www.wipo.int/madrid/en/how_to/manage/ownership.html

WIPO. (2019). How to Manage your International Registration: Overview. Retrieved from WIPO: https://www.wipo.int/madrid/en/how_to/manage/ 
THE INTERNATIONAL REGISTRATION OF TRADE MARKS UNDER...

WIPO. (2019). How to Use the Madrid System: Benefits of the Madrid System. Retrieved from https:// www.wipo.int/madrid/en/how_to/use/benefits.html

WIPO. (2019). Madrid Member Profiles. Retrieved from WIPO: https://www.wipo.int/madrid/ memberprofiles

WIPO. (2019). Members of the Madrid Union. Retrieved from WIPO: https://www.wipo.int/madrid/ en/members/ 